\title{
Containerized Onion Transplants: A Management System to Enhance Growth, Yield, and Quality
}

\author{
Maria A. Macias-Leon and Daniel I. Leskovar ${ }^{1}$ \\ Texas A\&M AgriLife Research, Department of Horticultural Sciences, Texas \\ A\&M University, 1619 Garner Field Road, Uvalde, TX 78807
}

Additional index words. Allium cepa, degree-days, bulb size distribution, anthocyanin, antioxidants

\begin{abstract}
In the United States, most short-day onions are direct seeded. With this method, plant stands can be reduced because of extreme temperatures, weed pressure, and soilborne diseases. Containerized transplants offer an alternative method of stand establishment with less seedling losses while producing uniform bulb sizes and high marketable yield. However, the use of transplants is not a widespread commercial practice because of the high cost of production. This study aims to select the best transplant strategies to improve onion crop performance in semiarid regions of southwest Texas or similar environments. Three sequential transplanting dates of early, mid, and late season (14 Nov., 8 Dec., and 9 Jan.) and two seedling densities of one seed per cell (T1) and three seeds per cell (T3) were evaluated on growth, yield, bulb quality, and phytonutrient content of three onion cultivars, two yellow ('Caramelo' and 'Don Victor'), and one red ('Lambada'). During early development, late-transplanted onions had an increase in plant height and greater leaf elongation rate than early and midtransplanted onions, whereas early plantings required more days to reach maturity than mid and late plantings. Overall, early and midtransplanting dates resulted in higher yields than late plantings. Although increasing seedling density (T3 vs. T1) did not significantly reduce marketable yield in early plantings, T1 produced a higher number of jumbo and colossal bulb sizes than T3. Onion quality was mostly affected by cultivar and not by transplant strategies. The technique of establishing onions from transplants grown from one plant per cell (T1) or multiple plants (T3) from early November to early December provides a practical and economical alternative to achieve earlier crops, while reducing the length of the production season, as planting date is delayed.
\end{abstract}

Onion (Allium cepa L.) is one of the most important commercial crops grown worldwide. Based on the minimum daylength required to bulb formation, onions are classified into short-, intermediate-, and long-day types. Short-day onions can begin bulb development when daylength exceeds 11-12 $\mathrm{h}$, intermediate onions between 13 and $14 \mathrm{~h}$, and long-day types more than $16 \mathrm{~h}$ (Brewster, 1994). In the Southwestern United States, most short-day onion cultivars are direct-seeded between early September and early November and grown to maturity from May to June. During early development, onions seedlings are highly susceptible to soil-borne diseases, extreme temperatures, and weeds, often reducing plant stands

Received for publication 6 Aug. 2018. Accepted for publication 31 Oct. 2018.

This research was partially supported by a Cropping System Seed Grant, Texas A\&M AgriLife Research, Texas A\&M University. We acknowledge the support of Speedling, Sun City, FL, and Alamo, TX, for the growth and supply of the transplants, to BASF for providing the seeds, and Kuan Qin, Michael Tidwell, Manuel Figueroa, and Dr. Desire Djidonou for their assistance in collecting data.

${ }^{1}$ Corresponding author. E-mail: d-leskovar@tamu. edu.
(Leskovar et al., 2004a). To compensate for these losses in plant population, growers typically increase the seeding density (Leskovar et al., 2012).

In some growing regions of the world, especially Mexico, onions are planted using containerized transplants grown previously in greenhouses. It is well known that a highquality onion transplant can produce higher yield and more uniform bulbs (Leskovar and Vavrina, 1999). However, the use of transplants is not a common practice followed in the United States because of the considerably higher cost of production when using multiple-cell tray containers (Leskovar et al., 2004b) and the lack of adaptable transplanting machines. In Georgia, the estimated transplant cost of production and setting is $\approx \$ 1370$ per ha (Boyhan et al., $2009)$, whereas it is more than $\$ 3500$ per ha in Florida and Texas in 2018 (Speedling, Inc., personal communication). To offset this cost, multiseeding in individual cells has been tested as an alternative to provide a greater number of seedlings per unit area at lower cost per plant (Leskovar et al., 2004a; Rubatzky and Yamaguchi, 1997). An early field study by Leskovar et al. (2004a) aimed at producing medium bulbs for export to Brazil, compared the effect of different establishment techniques in onion yield pro- duction, including bare-root and containerized transplants grown from one, two, and three seedlings per cell in 228 cell tray, which later were individually separated at transplanting or planting with two or three plants without separation. They found that total yields were not statistically different among different densities in containerized and bare-root transplants, and that two and three seeds per cell were best to obtain the target $50-70 \mathrm{~mm}$ bulb diameter category. Therefore, planting multiple seeds in individual cells can be an alternative and cost-efficient system for onion production compared with direct seeding and onion sets.

Onion transplants grown under low light conditions [photosynthetically active radiation $(P A R)<800 \mathrm{mmol} \cdot \mathrm{m}^{-2} \cdot \mathrm{s}^{-1}$ ] and low temperatures in the United Kingdom showed a negative correlation between transplant size and time to onset of bulbing and maturity, and positive correlation to bulb weight. Conversely, transplants grown under high light intensities $\left(P A R>1500 \mathrm{mmol} \cdot \mathrm{m}^{-2} \cdot \mathrm{s}^{-1}\right)$ and high temperatures in Sri Lanka showed a positive correlation between transplant size, onset of bulbing, and maturity (Mettananda and Fordham, 1999). Therefore, manipulation of the transplant size during the nursery stage could optimize the time of bulbing and final bulb size. With favorable light and temperature conditions, small transplants should bulb earlier, whereas it has been reported that large onion transplants should mature later and increase bulb size (Brewster, 1990b).

The interaction of planting date and daylength influences plant survival, growth, bulbing, and ultimately bulb size. Previous research showed that late plantings during autumn in the Northern Hemisphere usually result in a reduction in plant survival and yield (Richwine, 1990). Gaskell (1998) observed that planting dates are critical for superior foliage development and bulb size. An experiment conducted with short- and intermediate-day onions in Queensland, Australia (lat. $27^{\circ} 35^{\prime} \mathrm{S}$, long. $152^{\circ} 23^{\prime} \mathrm{E}$ ) in the Southern Hemisphere showed April plantings producing the greatest yield as compared with February, March, May, and June plantings (Jackson et al., 1997).

In New Mexico, early September plantings resulted in high levels of bolting and low yield; mid to late September reduced bolting and increased yields; whereas mid-October produced no bolting, but reduced yields (Corgan and Kedar, 1990). In Georgia, onions can be transplanted starting the first week of November until the last week of December, and still obtain reasonable yield and quality. For example, onions transplanted in December had a lower yield compared with those transplanted in November, but showed no differences from the onions transplanted in January (Boyhan et al., 2009). Similar results were observed by El-Rehim et al. (1997) in Egypt, where higher yields resulted from transplanting in November rather than February. Thus, determining optimal sowing and transplanting 
dates are critical to maximizing yield and bulb quality.

In 2016, onion represented the fifth most valuable vegetable in the United States with a fresh market value of $\$ 925$ million (USDA, 2016). Its value is attributed to its unique pungency and the ability to enhance other food flavors. Onion pungency is produced by the release of the enzyme allinase reacting with the flavor precursors S-alk(en)yl-cysteine sulfoxide when cells are disrupted (Lancaster and Boland, 1990). In addition, onions have numerous health benefits because they are a rich source of various phytonutrients such as anthocyanins, phenolic acids, flavonoids, and thiosulfates. Flavonoids continue to attract attention because of their potential implication in cardiovascular diseases, inflammation, and cancer (Middleton et al., 2000). Onions also have significant medicinal properties such as anticarcinogenic, antiasthmatic, antibiotic effects, antithrombotic activity, and antiplatelet effects (Griffiths et al., 2002). Antioxidants can inhibit oxidative reactions and help in functional performance of enzyme systems for self-defense mechanisms in cells (Lee et al., 2009). It is well known that plant chemical properties could vary according to weather conditions such as temperature and rainfall (Patil et al., 2012). To our knowledge, there are no studies emphasizing the influence and interactions of three management strategies (seedling density, planting date, and cultivar) on growth, yield, and onion quality. Thus, this study aims to evaluate the effects of three sequential planting dates and two seedling densities in multicelled trays on growth, yield components, bulb quality, and phytonutrient content of three short-day onion cultivars differing in scale color.

\section{Materials and Methods}

Plant material. The experiment was conducted using three short-day onion cultivars Don Victor, Lambada, and Caramelo (BASF, the Netherlands). 'Don Victor' is a goldyellow, globe-shaped cultivar, with a growing season of 170-175 d; 'Lambada' is an early maturing red round-shaped cultivar, with a growing season between 160-165 d; and 'Caramelo' is a yellow Granex cultivar, with a growing season of 170-175 d. Each cultivar was seeded on 8 Aug., 8 Sept., and 8 Nov. 2016 in polysterene speedling trays containing 392 cells $\left(4.84 \mathrm{~cm}^{2} \times 6.35 \mathrm{~cm}\right.$, and $14.75 \mathrm{~cm}^{3}$ cell volume), with one seed per cell (T1) and three seeds per cell (T3) on a Speedling tobacco peat lite mix media (Speedling, Sun City, FL) and covered with vermiculite grade 2-3-4 (W.R. Grace, Cambridge, MA). Seedlings were grown with the same experimental conditions in two nurseries, one at Alamo, TX, and the second at Ruskin, FL.

Experimental location. Onion seedlings were transplanted on three dates: early (14 Nov.), mid (8 Dec.), and late (9 Jan.) season into the field at the Texas AgriLife Research and Extension Center at Uvalde, TX (lat. $29^{\circ} 12^{\prime} 57.6^{\prime \prime} \mathrm{N}$, long. 99 $45^{\circ} 21.6^{\prime \prime} \mathrm{W}$ ). This location has a semiarid to subhumid condi- tions. During the study period, the total seasonal precipitation was $337 \mathrm{~mm}$ and seasonal average temperature, relative humidity, and daily light integral were $18.8^{\circ} \mathrm{C}$, $68.8 \%$, and $58.2 \mathrm{~mol} \cdot \mathrm{m}^{-2} \cdot \mathrm{d}^{-1}$, respectively (Fig. 1).

Cumulative degree-days (CDD) calculation. Cumulative degree-days at each sampling date were calculated as the sum, between the date of transplanting and the sampling date, of the degrees greater than $4{ }^{\circ} \mathrm{C}$ base temperature for onion (Finch-Savage and Phelps, 1993) based on the average daily temperature:

$$
\mathrm{CDD}_{\text {sampling } x}=\sum_{\text {day } 0}^{\text {sampling } x} \frac{T_{\max }-T_{\min }}{2}-T_{\text {base }} \text {, }
$$

where $T_{\max }$ and $T_{\min }$ correspond to the average maximum and minimum daily temperature recorded on a certain day. Cumulative rainfall and $\mathrm{CDD}$ at representative growing days are shown in Table 1 .

Field management. Seedlings were planted on single raised beds separated $1.01 \mathrm{~m}$ apart, $6 \mathrm{~m}$ long, and with two rows per bed. Seedlings were placed at $10 \mathrm{~cm}$ within each row and $20 \mathrm{~cm}$ between row planting (density of 200,000 plants/ha), with 120 plants per experimental unit $(6 \mathrm{~m} \times 1 \mathrm{~m} \times 2$ rows $)$ and four replications. Preplant fertilization was provided by incorporating into beds before transplanting with $50 \mathrm{~N}-0 \mathrm{P}-69 \mathrm{~K} \mathrm{~kg} \cdot \mathrm{ha}^{-1}$. Additional postplant fertilization was provided as fertigation through the drip. Total seasonal fertilization for all planting dates was $\approx 134 \mathrm{~N}-$ $50 \mathrm{P}-69 \mathrm{~K} \mathrm{~kg} \cdot \mathrm{ha}^{-1}$.

Growth attributes. After transplanting, plant height $(\mathrm{PH})$ and neck diameter (ND) were measured at 15, 60, 90, and $120 \mathrm{~d}$ after transplanting (DAT). To quantify leaf elongation at each growth stage, relative leaf elongation rate (RLER) was calculated as followed:

$$
\mathrm{RLER}=\frac{\ln \mathrm{PH}_{2}-\ln \mathrm{PH}_{2}}{t_{2}-t_{1}} \times 10,
$$

where $\ln \mathrm{PH}_{2}$ and $\ln \mathrm{PH}_{2}$ are the natural logarithms of the $\mathrm{PH}$ at time one $t_{1}$ and time two $t_{2}$, respectively.

Plants were harvested from $4.5 \mathrm{~m}$ plots when an average of $80 \%$ of the pseudostems had broken at the neck. At harvest, bulbs were sorted mechanically by diameter into four classes: small $(35-50 \mathrm{~mm})$, medium $(50-76 \mathrm{~mm})$, jumbo (76-102 mm), or colossal (>102 mm). After sorting, six onion bulbs per replication were collected and individually measured for bulb diameter and height, and then stored up to 2 weeks for chemical analysis.

Chemical quality. Pyruvic acid (PyA) and total soluble solids (TSS) measurements. For the onion chemical analysis, first the outer scales, basal plate, and neck were removed. Then, the central part of the onion was blended in a home mixer without adding water, and juice was collected after filtering the puree through a filter paper no. 41 (Whatman; GE Healthcare Life Sciences, UK). Then, the onion juice was frozen and kept at $-20{ }^{\circ} \mathrm{C}$ until analysis.

The PyA content of the onion juice was measured by the automated method described by
Yoo et al. (2011). Samples and reagent volumes were adjusted for the reaction to fit in a $1-\mathrm{mL}$ vial. Ten microliters of undiluted onion juice was combined in cuvettes with $300 \mu \mathrm{L}$ DNPH $\left(125 \mathrm{mg} \cdot \mathrm{L}^{-1}\right.$ in $\left.2 \mathrm{~N} \mathrm{HCl}\right)$ solution using an auto-dispenser, EasyChem Plus (Chinchilla Scientific, Oak Brook, IL). The mixture was incubated for $10 \mathrm{~min}$, and then $600 \mu \mathrm{L} \mathrm{NaOH}$ $(1.0 \mathrm{~N})$ was added and incubated for $51 \mathrm{~s}$. Absorbance was read at $405 \mathrm{~nm}$. Total PyA concentration was calculated using the standard curve for PyA in a range between 2 and $10 \mu \mathrm{mol} \cdot \mathrm{mL}^{-1}$. Results were expressed as $\mu \mathrm{mol}$ of PyA equivalents per $\mathrm{mL}$ (Lee et al., 2015). For the total soluble solid content, a drop of the aliquot of the onion juice was used and measured by a digital refractometer (Palette-PR32 $\alpha$, ATAGO, Bellevue, WA).

Anthocyanin content. An aliquot of the onion juice prepared for the PyA measurement was used. Two hundred microliters of the juice were mixed with $2 \mathrm{~mL}$ of $1 \% \mathrm{HCl}$ diluted in $100 \%$ methanol. The absorbance of the mixture was measured with a Genesis 10S ultraviolet-Vis spectrophotometer (Thermo-Scientific, Madison, WI) at $530 \mathrm{~nm}$. Total anthocyanin concentration was calculated by using the molar coefficient factor of cyanidin-3-glucoside (anthocyanin extracted from chrysanthemum) of 29,600. Results were expressed as microgram of cyanidinglucoside equivalents per $\mathrm{mL}$ (Lee et al., 2015).

Antioxidant capacity (DPPH). Antioxidant capacity (AOA) by [2-2diphenyl-1-picrylhydrazal] (DPPH) assay was determined by the spectrophotometry method described by Lee et al. (2015), with some modifications. The reaction solution was prepared by dissolving $20 \mathrm{mg}$ of DPPH in $1 \mathrm{~L}$ of methanol $(100 \%)$. Then, $2 \mathrm{~mL}$ of the reaction solution was added to $20 \mu \mathrm{L}$ of onion juice and incubated for $2 \mathrm{~h}$ in the dark. The absorbance of the mixture was measured with a spectrophotometer at 515 $\mathrm{nm}$. The AOA was calculated using the standard curve in gallic acid in a range between 10 and $60 \mu \mathrm{g} \cdot \mathrm{mL}^{-1}$. Methanol $100 \%$ was used as a blank. Results were expressed as $\mu \mathrm{g}$ of gallic acid equivalents (GAE) per $\mathrm{mL}$ (Lee et al., 2015).

Statistical analysis. The field experiment followed a randomized complete block design with three factors (three onion cultivars, three plant densities, and three planting dates) and four replications. Transplants were grown at two locations (Alamo, TX, and Ruskin, FL) to assess the effect of the nursery-growing environment on the transplant quality, growth, and yield. However, all growth attributes discussed correspond to the transplants grown at Alamo, TX, because transplants grown at Ruskin, FL, displayed similar trends. All treatments and growth attributes were analyzed by analysis of variance using JMP13 (SAS Institute, Cary, NC). Mean differences among treatments were compared by least significant difference at $\alpha=0.05$.

\section{Results}

\section{Growth attributes}

Relative leaf elongation rate. Planting dates affected RLER of the three cultivars, 

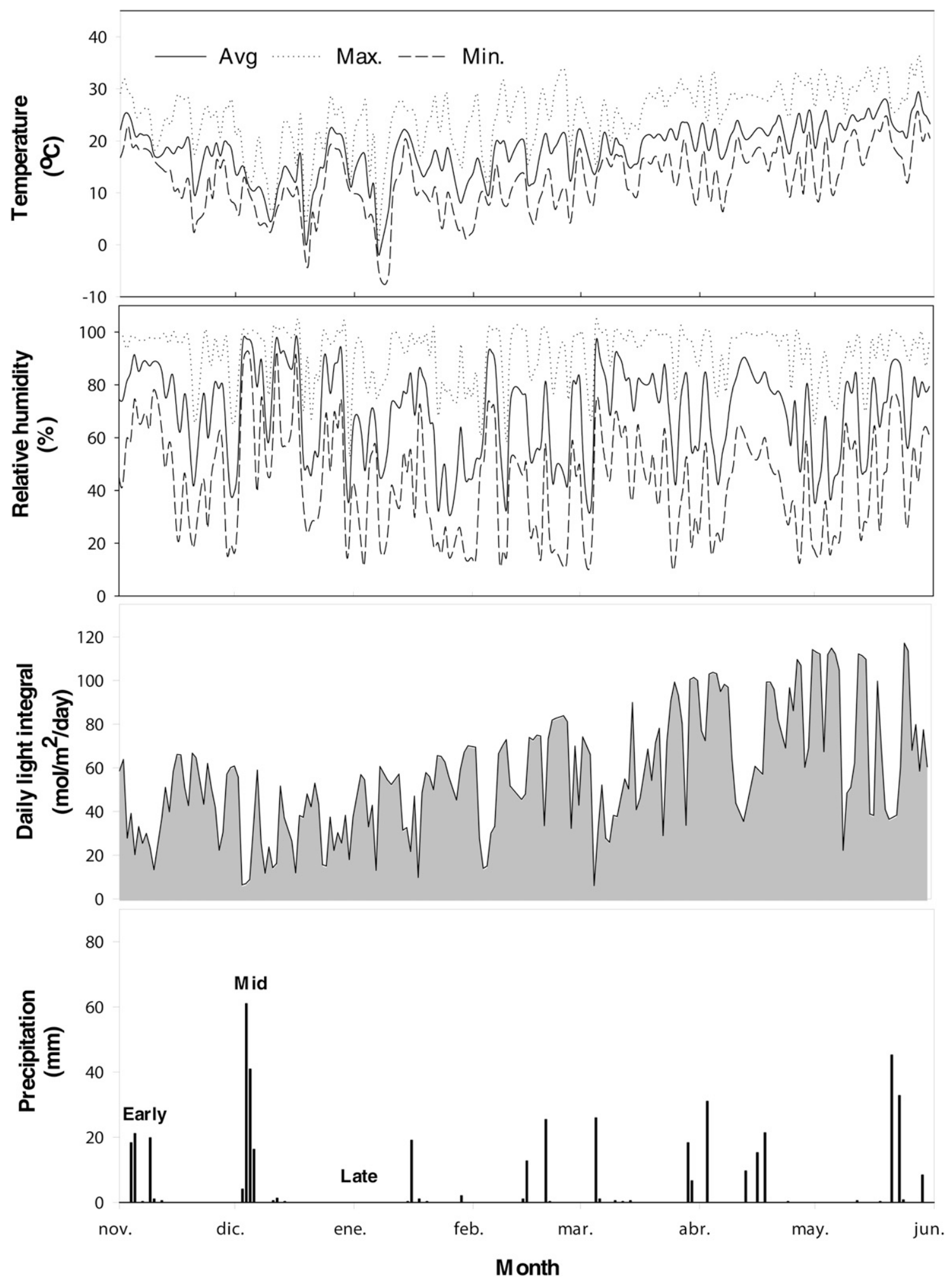

Fig. 1. Seasonal growing conditions at Texas A\&M Agrilife Research and Extension Center, Uvalde, TX. Maximum (T.max), minimum (T.min), and average (T. avg) temperature; Maximum (RH.max), minimum (RH.min), and average (RH.avg) relative humidity; Daily light integral; and cumulative precipitation.

Table 1. Cumulative degree-days (CDD) and rainfall accumulation at days after transplanting (DAT).

\begin{tabular}{|c|c|c|c|c|c|c|}
\hline \multirow[b]{2}{*}{ Plant sampling } & \multicolumn{2}{|c|}{ Early } & \multicolumn{2}{|c|}{ Mid } & \multicolumn{2}{|c|}{ Late } \\
\hline & $\mathrm{CDD}$ & $\overline{\text { Rainfall }}$ & $\overline{\mathrm{CDD}}$ & $\overline{\text { Rainfall }}$ & $\overline{\mathrm{CDD}}$ & Rainfall \\
\hline $15 \mathrm{DAT}$ & 193 & 0 & 75 & 2 & 181 & 21 \\
\hline 60 DAT & 734 & 145 & 741 & 64 & 910 & 90 \\
\hline 90 DAT & 1,039 & 186 & 1,097 & 92 & 1,363 & 193 \\
\hline $120 \mathrm{DAT}$ & 1,439 & 214 & 1,567 & 194 & & \\
\hline
\end{tabular}


they all followed similar patterns with minimal variations (Table 2). During early development (15-60 DAT), late plantings displayed the highest RLER, followed by the midplanting date, whereas the early planting date had the lowest RLER. The maximum growth rate occurred for the midtransplanting date at 60-90 DAT, which on average had a $7.5 \%$ and $8.8 \%$ increase $(1.47$ vs. 1.36 vs $\left.1.34 \mathrm{~mm} \cdot \mathrm{cm}^{-1} \cdot \mathrm{d}^{-1}\right)$ in RLER when compared with late and early plantings, respectively (Table 2). Late growth displayed a higher RLER in early plantings compared with midplantings $\left(1.50 \mathrm{vs} .1 .38 \mathrm{~mm} \cdot \mathrm{cm}^{-1} \cdot \mathrm{d}^{-1}\right)$. Late-planted onions reached maturity before reaching 120 DAT. In terms of transplant density (across cultivars and planting dates), onions grown from one seed per cell (T1) showed a greater RLER than onions grown from three seeds per cell (T3) during early and middevelopment (up to 90 DAT).

Plant height. Overall, PH was significantly affected by planting date, except at 15 DAT where not significant differences between treatments were observed (Table 3 ). During early development at 60 DAT, PH increased as planting date was delayed from early to late planting; at $90 \mathrm{DAT}, \mathrm{PH}$ was higher for the midtransplanting, and at 120 DAT for the early transplanting (Fig. 2). In terms of cultivar, $\mathrm{PH}$ displayed similar trends across planting dates and planting densities, except 'Don Victor' and 'Lambada' which showed on T3 treatments a slight increase in $\mathrm{PH}$ at 120 DAT compared with T1 at midtransplanting (Fig. 2E and H). The maximum $\mathrm{PH}$ increase occurred in late-transplanted $\mathrm{T} 1$ 'Don Victor', from 15 to 60 DAT (Fig. 2F), with a $223 \%$ increase (from 22.6 to 73.08 $\mathrm{cm})$. The decline in $\mathrm{PH}$ at 120 DAT on the midtransplanted onions (Fig. 2B, E, and $\mathrm{H}$ ) was related to leaf senescence as plants were approaching maturity, whereas latetransplanted onions were harvested at 113 DAT.

Neck diameter. Overall, ND was mainly affected by planting date and plant density than by cultivar (Table 3), although there were significant three-way interactions at 60 and 90 DAT. During early growth (15 DAT), ND did not vary in response to planting date or cultivar (Table 3; Fig. 3). Differences in ND among the three planting dates increased later in the development (60-120 DAT). During early plantings, ND increase was constant across the growing stages (Fig. 3A, $\mathrm{D}$, and $\mathrm{G}$ ), whereas for midplantings, ND reduced by $15 \%$ as bulbs were approaching maturity from 90 DAT to 120 DAT (Fig. 3B, $\mathrm{E}$, and $\mathrm{H}$ ), whereas for the late plantings, ND was completely closed and ready for harvest before reaching 120 DAT. In terms of plant density, T1 treatment displayed a greater ND than T3 across the growing season in early plantings. Similar trends were observed at mid and late plantings, with $\mathrm{T} 1$ having a greater ND than T3 when measured at 60 DAT. During midplantings, 'Caramelo' T3 treatment displayed a significant neck reduction at 120 DAT (Fig. 3B), which was opposite to that of late plantings, where

Table 2. Relative leaf elongation rate (RLER) affected by planting date (early, 14 Nov.; mid, 8 Dec.; and late, 9 Jan.), onion cultivar (Caramelo, Don Victor, and Lambada), and plant density (T1, one plant per cell and T3, three plants per cell).

\begin{tabular}{|c|c|c|c|c|c|}
\hline \multirow[b]{2}{*}{ Planting date } & \multirow[b]{2}{*}{ Cultivar } & \multirow[b]{2}{*}{ Plant density } & \multicolumn{3}{|c|}{$\operatorname{RLER}\left(\mathrm{mm} \cdot \mathrm{cm}^{-1} \cdot \mathrm{d}^{-1}\right)$} \\
\hline & & & 15-60 DAT & 60-90 DAT & 90-120 DAT \\
\hline \multirow{6}{*}{ Early } & Caramelo & T1 & $0.82 \mathrm{Cab}$ & $1.37 \mathrm{Ba}$ & $1.48 \mathrm{Ad}$ \\
\hline & & T3 & $0.78 \mathrm{Cc}$ & $1.33 \mathrm{Bbc}$ & $1.49 \mathrm{Acd}$ \\
\hline & Don Victor & T1 & $0.80 \mathrm{Cabc}$ & $1.34 \mathrm{Babc}$ & $1.52 \mathrm{Aa}$ \\
\hline & & T3 & $0.77 \mathrm{Cc}$ & $1.32 \mathrm{Bc}$ & 1.51 Aabc \\
\hline & Lambada & $\mathrm{T} 1$ & $0.83 \mathrm{Ca}$ & $1.35 \mathrm{Bab}$ & $1.52 \mathrm{Aab}$ \\
\hline & & T3 & $0.79 \mathrm{Cbc}$ & $1.32 \mathrm{Bbc}$ & $1.49 \mathrm{Abcd}$ \\
\hline \multirow[t]{6}{*}{ Mid } & Caramelo & T1 & $0.88 \mathrm{Ba}$ & $1.49 \mathrm{Aa}$ & $1.38 \mathrm{Ba}$ \\
\hline & & T3 & $0.84 \mathrm{Bc}$ & 1.47 Aabc & $1.33 \mathrm{Bc}$ \\
\hline & Don Victor & T1 & $0.86 \mathrm{Bbc}$ & $1.48 \mathrm{Aab}$ & $1.41 \mathrm{Bab}$ \\
\hline & & $\mathrm{T} 3$ & $0.86 \mathrm{Bbc}$ & $1.47 \mathrm{Abc}$ & $1.43 \mathrm{Bbc}$ \\
\hline & Lambada & $\mathrm{T} 1$ & $0.87 \mathrm{Bab}$ & $1.47 \mathrm{Aabc}$ & $1.37 \mathrm{Ba}$ \\
\hline & & T3 & $0.84 \mathrm{Bc}$ & $1.46 \mathrm{Ac}$ & $1.40 \mathrm{Bc}$ \\
\hline \multirow[t]{6}{*}{ Late } & Caramelo & T1 & $0.93 \mathrm{Aa}$ & $1.38 \mathrm{Bab}$ & \\
\hline & & T3 & $0.92 \mathrm{Aab}$ & $1.38 \mathrm{Bab}$ & \\
\hline & Don Victor & $\mathrm{T} 1$ & $0.94 \mathrm{Aa}$ & $1.41 \mathrm{Bab}$ & \\
\hline & & T3 & $0.90 \mathrm{Ab}$ & $1.43 \mathrm{Ba}$ & \\
\hline & Lambada & T1 & $0.92 \mathrm{Aab}$ & $1.39 \mathrm{Bab}$ & \\
\hline & & $\mathrm{T} 3$ & $0.89 \mathrm{Ab}$ & $1.17 \mathrm{Bb}$ & \\
\hline
\end{tabular}

Results that are significantly different at the $P=0.05$ level of significance were determined by least significant difference. Upper case letters represent multiple comparisons of the mean to the effect between planting dates. Lower case letters represent multiple comparisons for the effect due to onion cultivar and plant densities.

DAT $=$ days after transplanting.

Table 3. Significance ( $P$ value) of main and interaction effects on plant growth variables of onion.

\begin{tabular}{lrrrrc}
\hline Variable & DAT & Planting date & Cultivar & Plant density & Three-way interaction \\
\hline Plant height & 15 & 0.100 & 0.062 & $<0.001$ & 0.252 \\
& 60 & $<0.001$ & 0.185 & $<0.001$ & 0.089 \\
& 90 & $<0.001$ & 0.024 & 0.007 & 0.373 \\
Neck diameter & 120 & $<0.001$ & $<0.001$ & 0.114 & 0.044 \\
& 15 & 0.497 & 0.153 & $<0.001$ & 0.432 \\
& 60 & $<0.001$ & 0.091 & $<0.001$ & 0.453 \\
& 90 & $<0.001$ & 0.010 & 0.007 & 0.013 \\
& 120 & $<0.001$ & 0.073 & 0.024 & 0.049 \\
\hline
\end{tabular}

$\mathrm{DAT}=$ days after transplanting

'Caramelo' T1 treatment showed a similar ND than T3 treatment (Fig. 3C).

Maturity. Delaying the planting time from November to January resulted in a progressive reduction in the crop cycle. Onions transplanted on 14 Nov. (early) were harvested 176 DAT (24 Apr.); those transplanted on 8 Dec. (mid) were harvested 162 DAT ( 9 May); and those transplanted on 9 Jan. (late) were harvested 130 DAT (19 May).

\section{Yield}

Alamo, TX. Yield was significantly affected by the main effects and the interaction of planting date, onion cultivar, and plant density $(P=0.036)$. Across all cultivars, marketable bulb yield was lower, by $26 \%$ in late plantings compared with both early and midplantings, whereas the two latter plantings showed not significant differences. Among cultivars, 'Don Victor' had the highest marketable yield, $14 \%$ and $37 \%$ higher than the yield of 'Caramelo' and 'Lambada', respectively. In terms of seedling density, T3 treatment slightly reduced marketable yield by $14 \%$ compared with $\mathrm{T} 1$. In terms of interaction effects, during early plantings, 'Caramelo' and 'Don Victor' did not display a significant reduction on yield at increasing seedling density, in contrast to 'Lambada', with a $24 \%$ yield reduction from $\mathrm{T} 1$ to $\mathrm{T} 3$.
For midplantings, the three cultivars significantly reduced yield when increasing seedling density. Conversely, 'Caramelo' did not display any significant yield reduction during late plantings, whereas 'Don Victor' and 'Lambada' showed a yield reduction of $31 \%$ and $30 \%$, respectively (data not shown). Average bulb weight (ABW) was affected by planting date, cultivar, and plant density main effects. Midplantings resulted in the greatest ABW (305 g) as compared with early (298 g) and late plantings (237 g). Overall, ABW for 'Don Victor' was $20 \%$ and $37 \%$ greater compared with that of 'Caramelo' and 'Lambada', respectively. In terms of plant density, $\mathrm{ABW}$ decreased by $13 \%$ with the increase in seeding density (T3).

Even though bulb number was similar across all treatments (Table 4), bulb size distribution was significantly affected by planting time, onion cultivar, and plant density (Fig. 4). In particular, a high volume of small bulbs $(35-50 \mathrm{~mm})$ occurred in the late planting, whereas the early planting had the highest percentage of bulbs in the colossal category $(>102 \mathrm{~mm})$ and the lowest production of small bulbs. Among cultivars, 'Don Victor' produced the highest percentage of bulbs in the categories jumbo and colossal (76-102 $\mathrm{mm}$ and $>102 \mathrm{~mm}$ ) during early plantings, whereas 'Caramelo' produced the 
Early
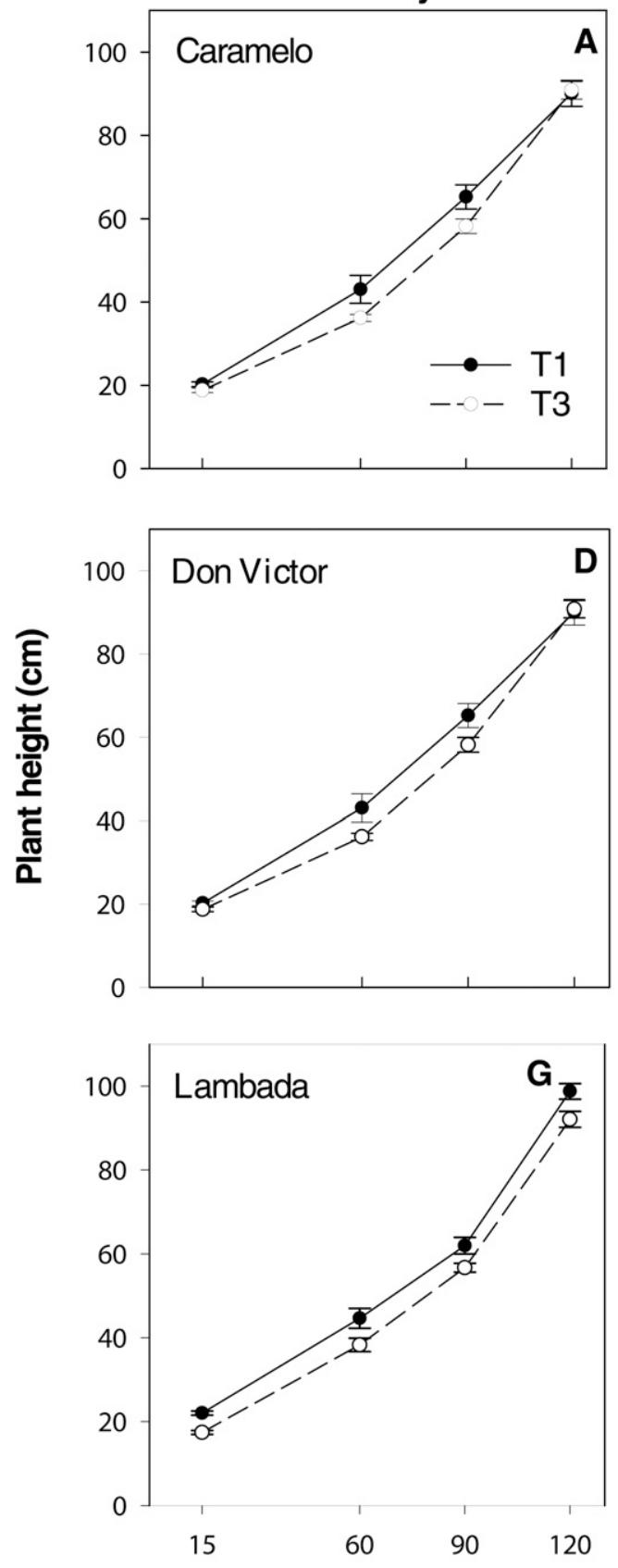

Mid
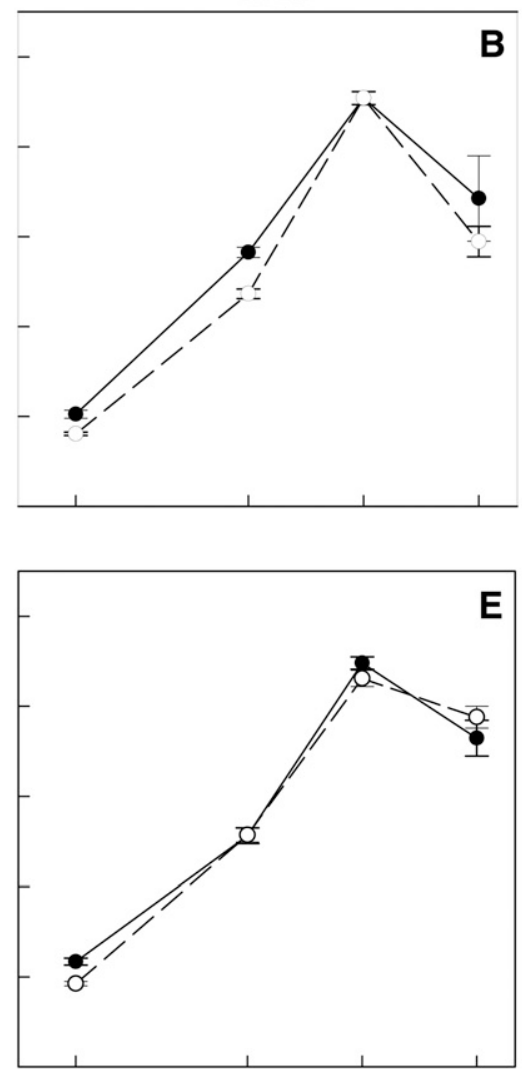

E

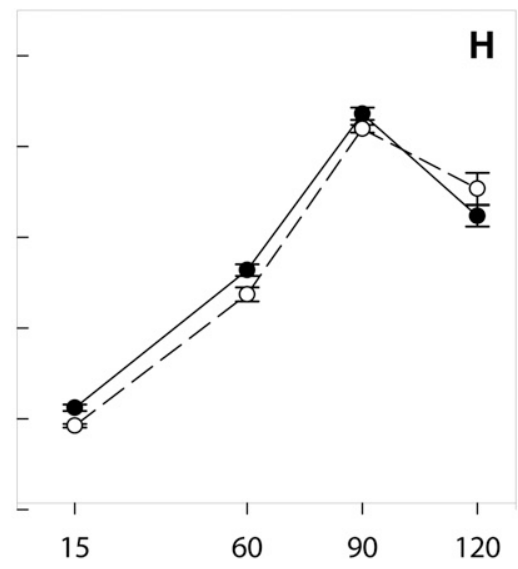

Late
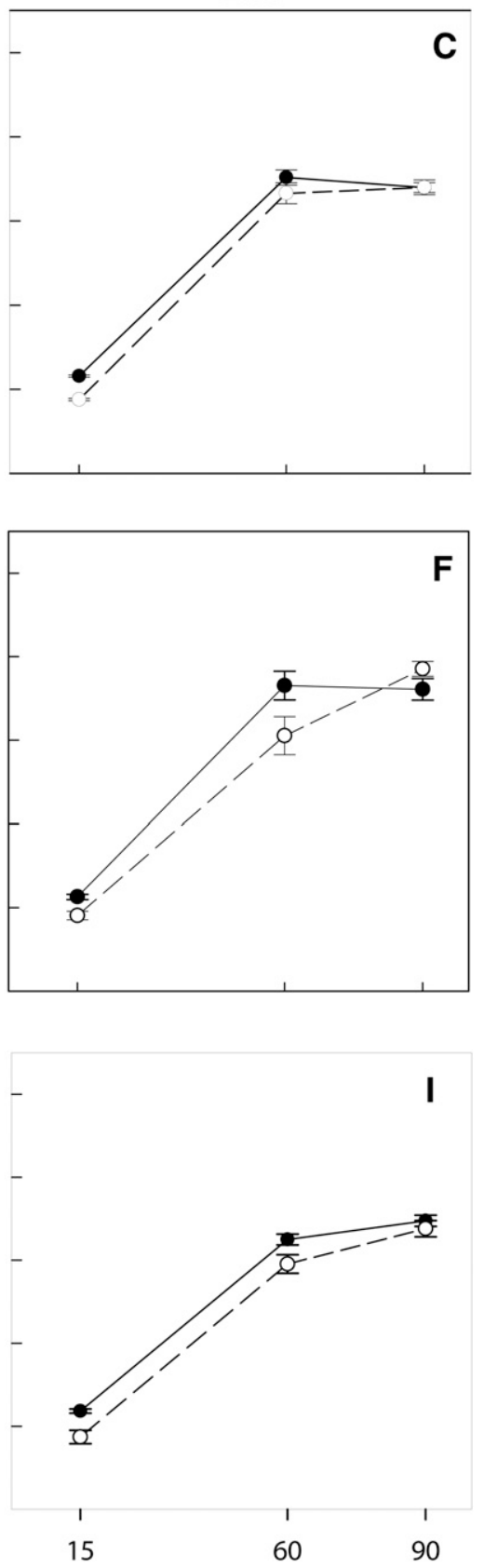

Days after transplanting

Fig. 2. Effect of planting date (early, 14 Nov.; mid, 8 Dec.; and late, 9 Jan.), onion cultivar (Caramelo, Don Victor and Lambada), and plant density (one plant per cell, T1 and three plants per cell, T3) on plant height. 'Caramelo' (A) early, (B) mid, and (C) late; 'Don Victor' (D) early, (E) mid, and (F) late; and 'Lambada' (G) early, (H) mid, and (I) late.

highest percentage in the small- and mediumsized categories (35-50 $\mathrm{mm}$ and 50-76 mm) during late plantings, and 'Lambada' lacking bulbs in the jumbo category during all planting dates (Fig. 4). Plant density also significantly affected bulb size grades, with $\mathrm{T} 1$ having a $35 \%$ of the total yield in the jumbo and colossal bulb size classes, whereas for T3 treatment, $25 \%$ of the final yield occurred in the small bulb category (Fig. 4).

Ruskin, FL. For transplants grown at Ruskin, differences in yield resulted in response to planting date, onion cultivar, and plant density main effects, and interaction between onion cultivar and planting date, as well as plant density and planting date (Table 4). Late plantings resulted in a $56 \%$ and $21 \%$ yield reduction compared with early and midplanting dates, respectively (not shown). Differences in yield among cultivars followed the same patterns as for Alamo transplants, with 'Don Victor' displaying the highest average yield $\left(45 \mathrm{t} \cdot \mathrm{ha}^{-1}\right)$, whereas 'Lambada' produced the lowest yield ( 33 t.ha ${ }^{-1}$ ) and 'Caramelo' with intermediate yield $\left(39 \mathrm{t} \cdot \mathrm{ha}^{-1}\right)$. In terms of plant density treatments, T3 reduced the total yield by $21 \%$ compared with T1. During early and midplantings, 'Don Victor' displayed the highest yield with $60 \mathrm{t} \cdot \mathrm{ha}^{-1}$ and $52 \mathrm{t} \cdot \mathrm{ha}^{-1}$, respectively, whereas 'Lambada' showed the lowest yield with $41 \mathrm{t} \cdot \mathrm{ha}^{-1}$ and $35 \mathrm{t} \cdot \mathrm{ha}^{-1}$ for early and midplantings, respectively (data not shown). Conversely, during late plantings, 'Caramelo' displayed the highest yield ( 26 t.ha ${ }^{-1}$ ) across cultivars, whereas 'Lambada' and 'Don Victor' showed similar yields (21 $\left.\mathrm{t} \cdot \mathrm{ha}^{-1}\right)$. In terms of plant density and planting date, significant differences were observed during early and late plantings, with $\mathrm{T} 1$ consistently displaying higher yields than T3 treatment, whereas during midplantings, 
Early
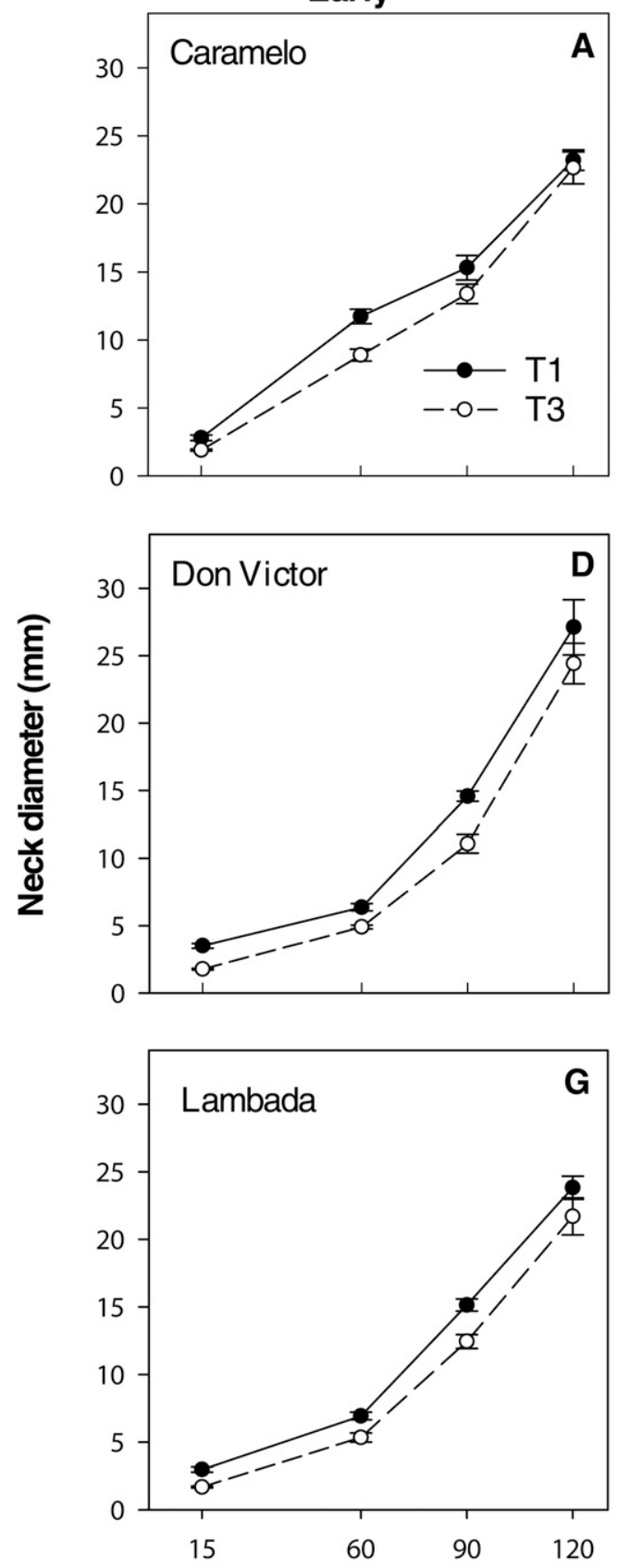

Mid
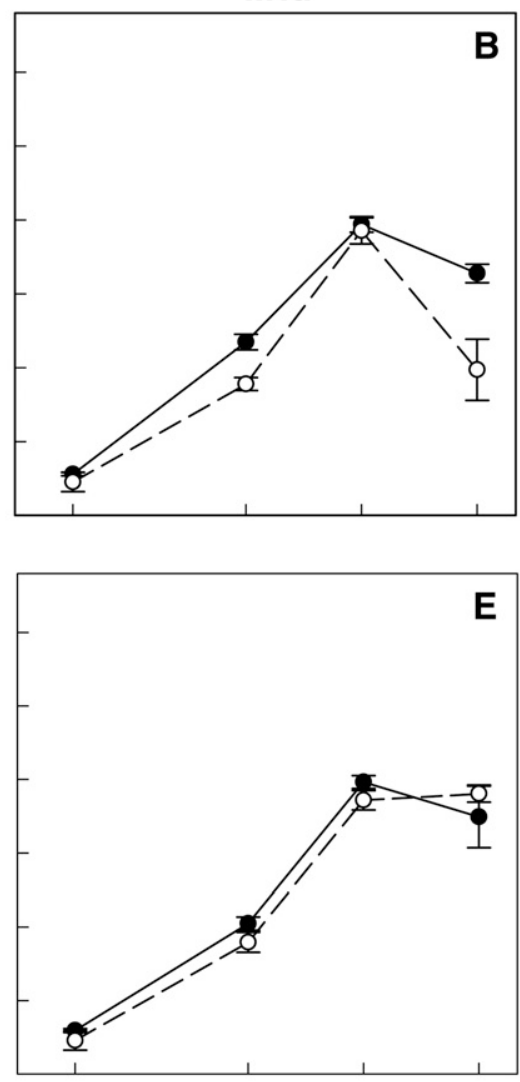

E

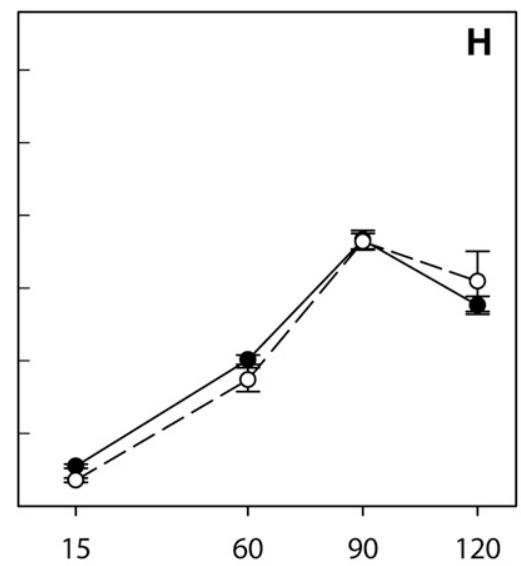

Late

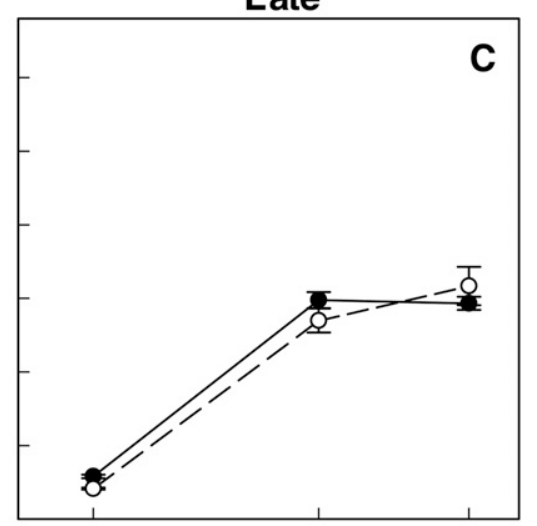

$\mathbf{F}$
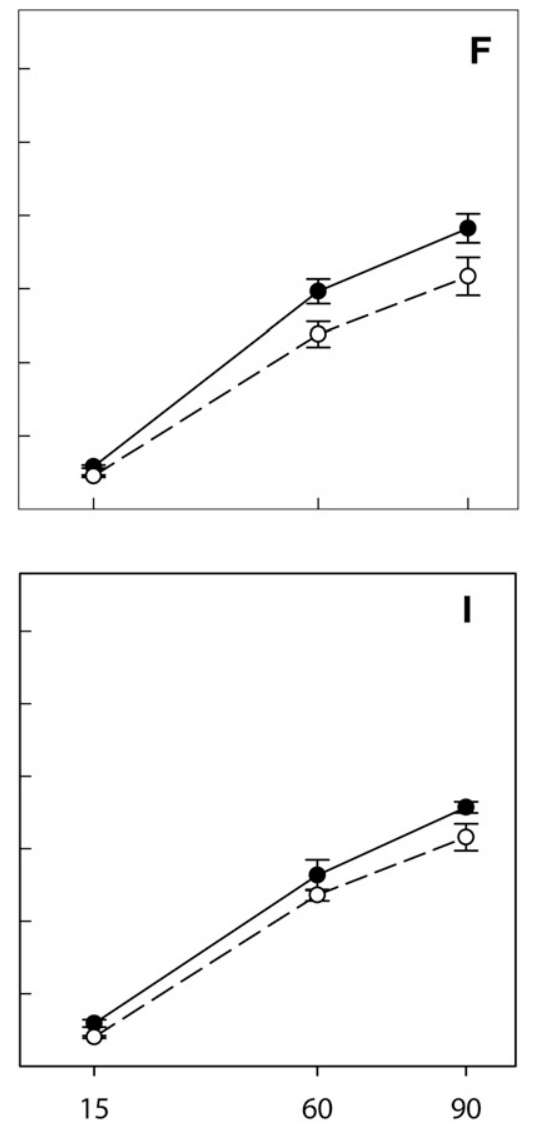

Days after transplanting

Fig. 3. Effect of planting date (early, 14 Nov.; mid, 8 Dec.; and late, 9 Jan.), onion cultivar (Caramelo, Don Victor, and Lambada), and plant density (one plant per cell, T1 and three plants per cell, T3) on neck diameter. 'Caramelo' (A) early, (B) mid, and (C) late; 'Don Victor' (D) early, (E) mid, and (F) late; and 'Lambada' (G) early, (H) mid, and (I) late.

no significant differences were observed between $\mathrm{T} 1$ and $\mathrm{T} 3$ treatments. $\mathrm{ABW}$ was affected by planting date, cultivar, and plant density. Onion bulbs from early planting resulted in a greater bulb ABW (301 g) compared with mid ( $271 \mathrm{~g})$ and late plantings (256 g). Among cultivars, 'Don Victor' displayed the highest ABW (336 g), followed by 'Caramelo' (266 g) and 'Lambada' (226 g). Increasing seedling density from one to three plants per cell showed an ABW reduction of $13 \%$. Conversely to what was observed for Alamo-grown transplants, bulb number was significantly affected by planting date, plant density, and interaction effects. Overall, T3 produced the highest number of bulbs during early planting, in contrast to mid and late plantings, with $\mathrm{T} 3$ treatments significantly reducing bulb number compared with $\mathrm{T} 1$ (Table 4).

In Ruskin, bulb size distribution was greatly affected by planting date, onion cultivar, and plant density. Midplanting dates produced the highest percentage of small bulbs, $36 \%$ and $13 \%$, compared with early and late plantings, respectively (Fig. 5). The highest percentage of jumbo and colossal bulbs occurred in the early planting. In terms of cultivars, bulb size distribution followed the same trends as Alamo transplants, with 'Don Victor' producing the highest number of bulbs in the colossal and jumbo categories. For seedling density, overall, T3 had the lowest percentage of jumbo and colossal size bulbs. Conversely, it produced a higher number of small- and medium-sized bulbs compared with T1 (Fig. 5).

\section{Onion quality}

Alamo, TX. Total soluble solids, PyA concentration, antioxidant capacity (DPPH assay), and anthocyanin contents were greatly affected by onion cultivar. 'Lambada' 
Table 4. Bulb number, bulb weight, and total marketable yield in response to main effects of planting date (PD), onion cultivar (C), and plant density (D) and their interactions.

\begin{tabular}{|c|c|c|c|c|c|c|}
\hline \multirow[b]{2}{*}{ Main effects } & \multicolumn{3}{|c|}{ Alamo, TX } & \multicolumn{3}{|c|}{ Ruskin, FL } \\
\hline & Bulb number (no./ha) & Bulb wt (g) & Yield $\left(\mathrm{t} \cdot \mathrm{ha}^{-1}\right)$ & Bulb number (no./ha) & Bulb wt (g) & Yield $\left(\mathrm{t} \cdot \mathrm{ha}^{-1}\right)$ \\
\hline \multicolumn{7}{|l|}{$\overline{\mathrm{PD}}$} \\
\hline Early & $168,642 \mathrm{a}$ & $298 \mathrm{a}$ & $50.11 \mathrm{a}$ & $172,683 \mathrm{a}$ & $306 \mathrm{a}$ & $51.67 \mathrm{a}$ \\
\hline Mid- & $166,331 \mathrm{a}$ & $305 \mathrm{a}$ & $50.30 \mathrm{a}$ & $151,670 \mathrm{~b}$ & $271 \mathrm{a}$ & $40.87 \mathrm{~b}$ \\
\hline Late & $156,250 \mathrm{a}$ & $237 \mathrm{~b}$ & $37.33 \mathrm{~b}$ & $93,121 \mathrm{c}$ & $256 \mathrm{~b}$ & $23.25 \mathrm{c}$ \\
\hline Significance & NS & $* * *$ & $* * *$ & $* * *$ & $* *$ & $* * *$ \\
\hline \multicolumn{7}{|l|}{$\mathrm{C}$} \\
\hline Caramelo & $171,246 \mathrm{a}$ & $278 \mathrm{~b}$ & $47.33 \mathrm{~b}$ & $143,498 \mathrm{a}$ & $266 \mathrm{~b}$ & $38.64 \mathrm{~b}$ \\
\hline Don Victor & $159,417 \mathrm{a}$ & $345 \mathrm{a}$ & $55.04 \mathrm{a}$ & $131,465 \mathrm{a}$ & $336 \mathrm{a}$ & $44.69 \mathrm{a}$ \\
\hline Lambada & $160,560 \mathrm{a}$ & $218 \mathrm{c}$ & $35.36 \mathrm{c}$ & $142,510 \mathrm{a}$ & $226 \mathrm{c}$ & $32.46 \mathrm{c}$ \\
\hline Significance & NS & $* * *$ & $* * *$ & NS & $* * *$ & $* * *$ \\
\hline \multicolumn{7}{|l|}{$\mathrm{D}$} \\
\hline $\mathrm{T} 1$ & $166,682 \mathrm{a}$ & $300 \mathrm{a}$ & $49.27 \mathrm{a}$ & $146,132 \mathrm{a}$ & $295 \mathrm{a}$ & $42.72 \mathrm{a}$ \\
\hline \multirow[t]{2}{*}{ T3 } & $160,799 \mathrm{a}$ & $260 \mathrm{~b}$ & $42.55 \mathrm{~b}$ & $132,183 \mathrm{a}$ & $257 \mathrm{~b}$ & $34.48 \mathrm{~b}$ \\
\hline & NS & $* *$ & $* * *$ & NS & $* *$ & $* * *$ \\
\hline \multicolumn{7}{|l|}{ Interactions } \\
\hline $\mathrm{C} \times \mathrm{PD}$ & NS & NS & NS & NS & NS & $* *$ \\
\hline $\mathrm{D} \times \mathrm{PD}$ & NS & NS & NS & $* *$ & NS & $* *$ \\
\hline $\mathrm{C} \times \mathrm{D} \times \mathrm{PD}$ & NS & NS & $* *$ & NS & NS & NS \\
\hline
\end{tabular}

Ns, $* * *, * * *$ Nonsignificant or significant at $P=0.05,0.001$, or $<0.001$ level of significance were determined by least significant difference. $\mathrm{C} \times \mathrm{D}$ and $\mathrm{C} \times \mathrm{D}$ interactions were not significantly different (not shown). For each planting date, cultivar, and plant density, means in a column with the same letter are not significantly different.

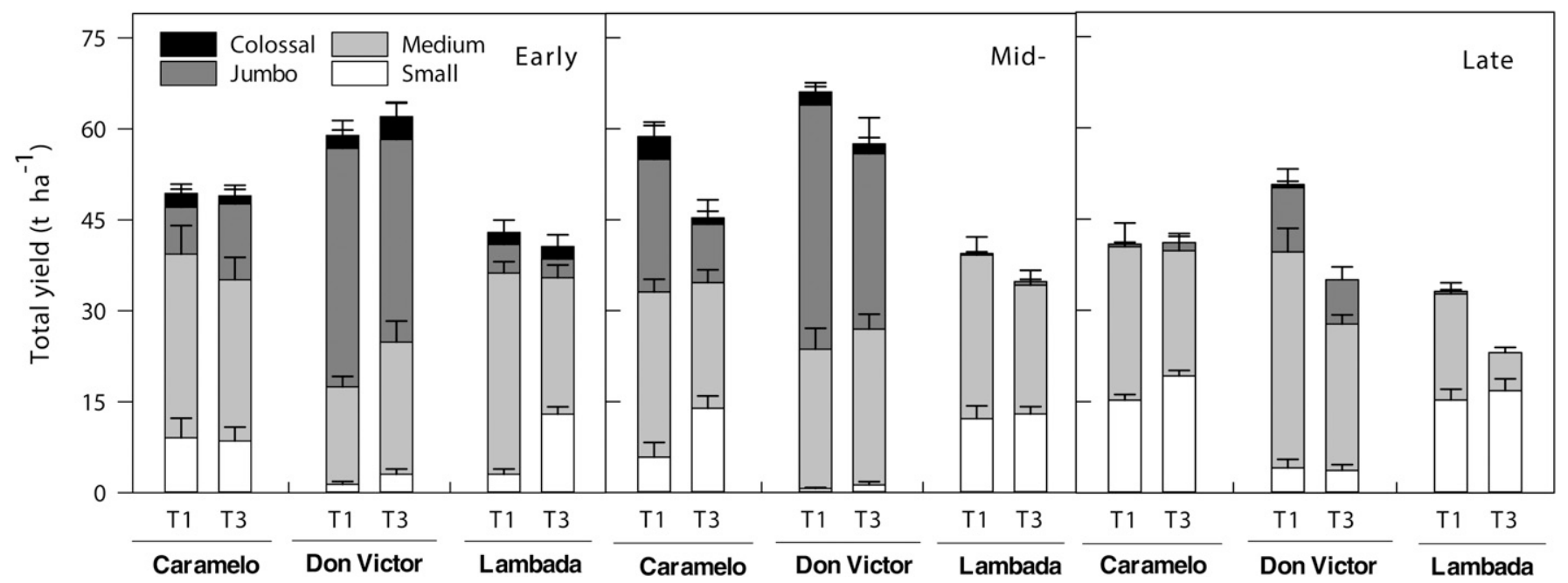

Fig. 4. Alamo, TX, grown transplants. Effect of planting date (early, 14 Nov.; mid, 8 Dec.; and late, 9 Jan.) and plant density (one plant per cell, T1 and three plants per cell, T3) of marketable grade bulbs of three onion short-day cultivars (Caramelo, Don Victor, and Lambada).

displayed the highest values across cultivars. Moreover, TSS and PyA concentration were also affected by planting date, with late planting displaying the highest TSS, whereas early transplanted onions accumulated a higher concentration of PyA (Table 5).

Ruskin, FL. The onion quality parameters from transplants grown in the Ruskin nursery were similar to those grown in Alamo, with 'Lambada' also displaying the highest values of TSS, PyA concentration, antioxidant capacity (DPPH), and anthocyanin content. Planting date had a significant effect in PyA content, with the highest accumulation of PyA occurring during early plantings and followed by late plantings, whereas midplanting dates had significantly increased the antioxidant capacity (Table 5).

\section{Discussion}

The differences in growth attributes $(\mathrm{PH}$, leaf elongation rate, and ND) at each de- velopmental stage across the three planting dates (early, mid, and late) were mainly due to air temperature differences (cumulative degree-days, Table 1) and weather conditions (Fig. 1). An early study by Currah and Proctor (1990) reported that onion growth, particularly $\mathrm{PH}$, is mostly regulated by temperature differences. During the early growth stage (15-60 DAT), onion PH and RLER were greater as planting date was delayed. This response was attributed to the increase in temperature from Nov. 2016 to Jan. 2017 (Fig. 1). At 60 DAT, early, mid, and late transplants accumulated a total of 734, 741, and 910 degree-days, respectively. A similar trend was observed in a study conducted by Tesfay et al. (2011) in South Africa, where three onion cultivars were grown under three sets of day/night temperatures and photoperiods and showed a leaf growth promotion at 405 and above degree-days under 12-h photoperiod. Conversely, a higher degree-days accumulation after 90 DAT for the midtrans- planted onions resulted in leaf senescence and a decline in RLER (Table 2).

It is well known that the closure of ND is associated with bulb maturity (Brewster et al., 1987). In mid and late plantings, the reduction in ND started at about 90 DAT. Considering the CDD, the results of these experiments suggest that an onion plant continues to grow vegetatively until it accumulates between 1097 and 1439 degree-days, followed by the progressive closure of ND as bulbs approach the harvest maturity. Mid and late plantings promoted an earlier ND closure as compared with early transplanted onions, reducing the number of days to reach bulb maturity. It is probable that higher temperatures (Fig. 1) during early development for mid and late plantings stimulated early bulbing, promoting a rapid leaf senescence, shortening the growing cycle. After 90 DAT, early, mid, and late plantings had accumulated 1039, 1097, and 1363 CDD, respectively (Table 1). Accordingly, early planting 


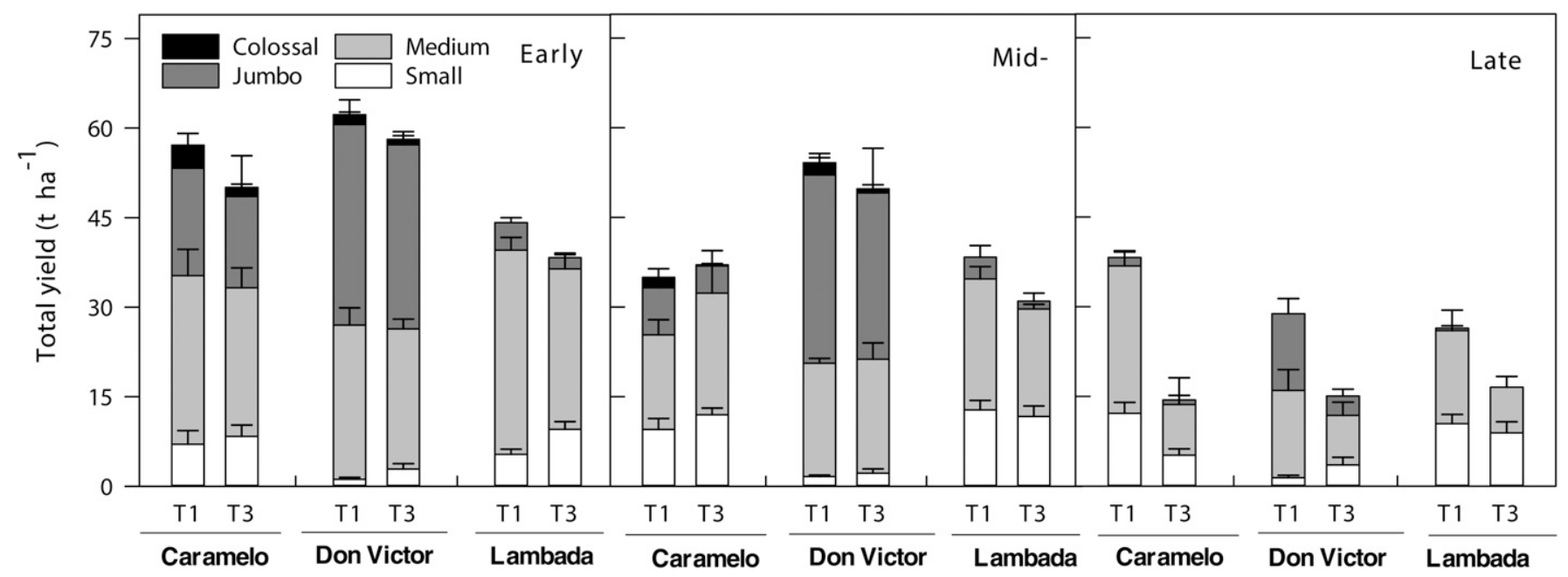

Fig. 5. Ruskin, FL, grown transplants. Effect of planting date (early, 14 Nov.; mid, 8 Dec.; and late, 9 Jan.) and plant density (one plant per cell, T1 and three plants per cell, T3) of marketable grade bulbs of three onion short-day cultivars (Caramelo, Don Victor, and Lambada).

Table 5. Effects of transplanting date, cultivar, and interactions on onion chemical properties.

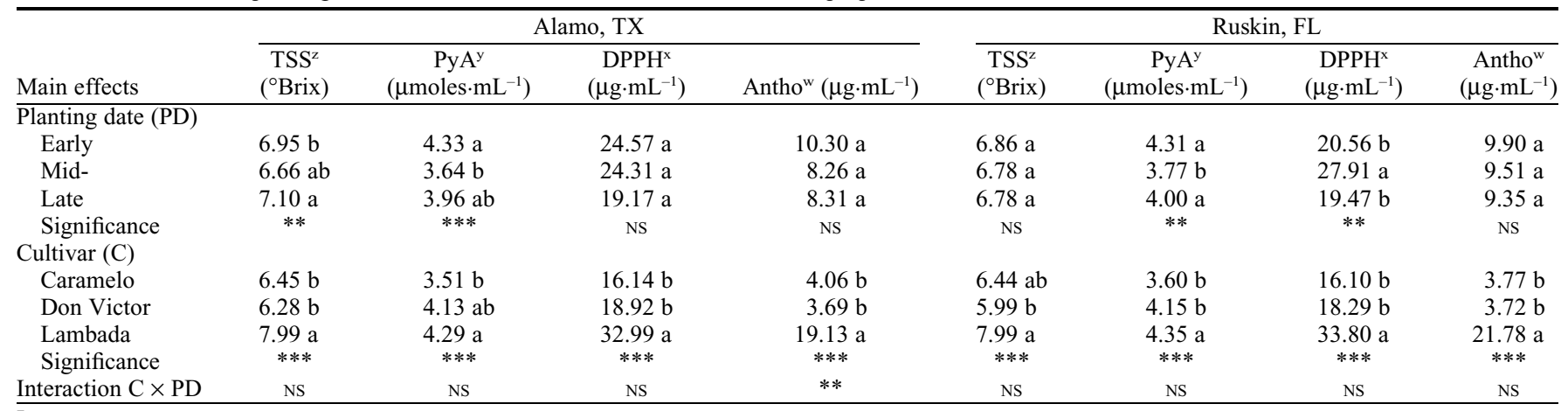

${ }^{\mathrm{z}}$ Total soluble solids.

${ }^{\mathrm{y}}$ Pyruvic acid.

x2-diphenyl-1-picrylhydrazyl assay.

${ }^{\mathrm{w}}$ Anthocyanin.

NS, * **, ***Nonsignificant or significant at $P=0.05,0.001$, or $<0.001$ level of significance were determined by LSD. C $\times \mathrm{D}, \mathrm{D} \times \mathrm{PD}$, and $\mathrm{C} \times \mathrm{D} \times \mathrm{PD}$ interactions were not significantly different (not shown). For each planting date and cultivar, means in a column with the same letter are not significantly different.

fits more closely the maturity profile of 'Don Victor' and 'Caramelo', needing between 170 and $175 \mathrm{~d}$ to reach maturity. On the other hand, 'Lambada' maturity profile is between 160 and $165 \mathrm{~d}$, fitting more closely when middate transplanting. The production of early maturing onions is a priority for growers, as they typically secure a higher market price. It is well known that daily temperature determines the length of growing stages in onions (Brewster, 1997), whereas photoperiod determines bulb initiation and maturity (Brewster, 1990a). The three cultivars used in this study showed a decrease in days to maturity as planting date was delayed. Arce (1995) observed similar results for three short-day onion cultivars growing in Rio Grande City, TX. In that study, physiological maturity of onions planted on 22 Sept. required 2 and $4 \mathrm{~d}$ more than those planted on 12 and 29 Oct., respectively. The crop transplanted late season resulted in early maturity as a result of a short period of low temperatures and long period of high temperatures (Khokhar et al., 1990).

Across planting dates and plant density, 'Don Victor' had the highest yield (55 t.ha $\left.{ }^{-1}\right)$, followed by 'Caramelo' ( $\left.47 \mathrm{t} \cdot \mathrm{ha}^{-1}\right)$ and 'Lambada' $\left(35 \mathrm{t} \cdot \mathrm{ha}^{-1}\right)$ for the transplants originated in Alamo, TX. The same tendency was observed for transplants grown in Florida, with increasing yields in the order of 'Don Victor' $\left(44 \mathrm{t} \cdot \mathrm{ha}^{-1}\right)>$ 'Caramelo' $\left(39 \mathrm{t} \cdot \mathrm{ha}^{-1}\right)>$ 'Lambada' (32 th ha $\left.{ }^{-1}\right)$. In this study, yield from onions transplanted early showed no significant differences between $\mathrm{T} 3$ and $\mathrm{T} 1$ treatments; however, for the transplants originated in Ruskin, FL, T3 displayed a significant yield reduction compared with $\mathrm{T} 1$ treatments when mid and late planted $(\mathrm{D} \times$ PD significant interaction, Table 4). Early planting ensures an extended period of bulb growth and an increase in yield and bulb size (De Ruiter, 1986). Khokhar et al. (1990) observed the same effects on 'Red Creole', 'Texas Early Grano', and 'Yalova' for onion cultivars transplanted at Islamabad, Pakistan, during the autumn and spring, with early plantings resulting in higher yield because of more canopy development before the onset of bulbing. Differences in bulb yield were also attributed to the differences of climatic conditions during mid and late plantings
(Fig. 1). In addition, yield reduction in onions transplanted on 8 Jan. resulted from freezing temperatures, with seedlings exposed to $-7{ }^{\circ} \mathrm{C}$ under windy conditions for a period of $5 \mathrm{~h}$ during the early establishment phase, causing a $30 \%$ decrease in survival. The onion capacity to survive winter temperatures varies by cultivar and plant age. The temperature for $50 \%$ loss was reported to be $-10.5{ }^{\circ} \mathrm{C}$ (Peffley et al., 1981). Onion freezing tolerance increases with time: the longer they have been in the field, the higher the freezing tolerance (Peffley et al., 1981).

An early study determined that plant density can be an efficient strategy to control bulb size and yield (Hatridge-Esh and Bennett, 1980), with an increase in plant density increasing the number of bulbs in the medium-size category. Nonetheless, in our study, bulb size distribution was mostly affected by the interaction of planting date $\times$ plant density rather than plant density by itself.

Onion quality was mainly affected by onion cultivar and planting date. On average, for both transplant sources (Texas and 
Florida), 'Lambada' displayed the highest TSS content ( $7.99{ }^{\circ}$ Brix $)$, followed by 'Caramelo' (6.45 ${ }^{\circ}$ Brix) and 'Don Victor' $\left(6.13{ }^{\circ}\right.$ Brix). TSS displayed a slight tendency of increasing with delaying the planting dates. Onions transplanted in January showed the highest TSS content $\left(7.10^{\circ}\right.$ Brix) followed by those transplanted in November and December (6.95 and $6.65{ }^{\circ}$ Brix, respectively) (Table 4). In Egypt, Kandil et al. (2013) observed the highest TSS levels in Texas Early Grano and Giza cultivars on 15 Dec. as compared with those on 1 Jan. and attributed these results to the suitable weather conditions during this planting time. Similar results were obtained in India by Patil et al. (2012) in five short-day white onion cultivars, with the lowest TSS $(16.2 \%)$ observed in early transplanting (15 Nov.), whereas the highest levels $(18.7 \%)$ were obtained in late transplants (1 Dec.). TSS content appears to have a negative correlation with growing temperature (Coolong and Randle, 2003). However, in southern Italy (lat. $40^{\circ} 38^{\prime} \mathrm{N}$, long. $14^{\circ} 58^{\prime} \mathrm{E}$ ), Caruso et al. (2014) observed a higher TSS content in onions transplanted on 18 Mar. rather than on 1 Feb.

Onion pungency greatly depends on cultivar, soil type, and other environmental factors (Hamilton et al., 1998). 'Lambada' displayed the highest PyA concentration, 4.29-4.35 $\mu \mathrm{mol} \cdot \mathrm{mL}^{-1}$, followed by 'Don Victor', 4.13-4.15 $\mu \mathrm{mol} \cdot \mathrm{mL}^{-1}$, and 'Caramelo' $3.51-3.60 \mu \mathrm{mol} \cdot \mathrm{mL}^{-1}$. Lee et al. (2009) concluded that pungency levels varied between breeding lines and cultivars, providing a clear evidence of genetic variation influencing pungency levels. In that study, PyA concentrations of seven breeding lines and two commercial cultivars harvested in Weslaco, TX (lat. $26^{\circ} 15^{\prime} \mathrm{N}$, long. $97^{\circ} 98^{\prime} \mathrm{W}$ ), on Apr. 2005 ranged from 1.9 to 8.3 $\mu \mathrm{mol} \cdot \mathrm{mL}^{-1}$ (Lee et al., 2009).

PyA levels did not show a tendency of increasing or decreasing with planting timing; onions transplanted on 14 Nov. showed the highest PyA content, with a combined average of $4.32 \mu \mathrm{mol} \cdot \mathrm{mL}^{-1}$, followed by onions transplanted on 8 Jan. and 9 Dec., 3.98 and $3.70 \mu \mathrm{mol} \cdot \mathrm{mL}^{-1}$, respectively (Table 5). In a study by Arce (1995), early plantings during Sept. 1993 displayed higher PyA levels $\left(7.03 \mu \mathrm{mol} \cdot \mathrm{mL}^{-1}\right)$ than December plantings $\left(6.48 \mu \mathrm{mol} \cdot \mathrm{mL}^{-1}\right)$; however, no differences were found in onions planted during November. Pungency is associated with temperature, with lower temperatures exhibiting greater pungency levels (Platenius and Knott, 1941). However, it is difficult to predict relationships between environmental factors and onion pungency (Lancaster and Boland, 1990).

'Lambada' (red onion) had a higher TSS content and PyA levels than 'Don Victor' and 'Caramelo' (yellow). These results are similar to those from a study by Lee et al. (2015), where they found TSS content had a broad range in different skin color cultivars, suggesting that TSS is more related to genotypes rather than bulb scale color (Lee et al., 2015).

'Lambada' displayed the greatest anthocyanin content $\left(19.13-21.78 \mu \mathrm{g} \cdot \mathrm{mL}^{-1}\right)$ as compared with 'Don Victor' (3.69-3.72 $\left.\mu \mathrm{g} \cdot \mathrm{mL}^{-1}\right)$ and 'Caramelo' (3.77-4.06 $\left.\mu \mathrm{g} \cdot \mathrm{mL}^{-1}\right)$ (Table 5). The partitioning of the significant cultivar $\times$ planting date interactions for Alamogrown transplants showed 'Lambada' having the highest levels of anthocyanin when transplanted early $\left(27.54 \mu \mathrm{g} \cdot \mathrm{mL}^{-1}\right)$ and the lowest in onions transplanted late $\left(15.85 \mu \mathrm{g} \cdot \mathrm{mL}^{-1}\right)$. By contrast, 'Caramelo' increased by 1.7fold when transplanted late from 2.85 to $4.98 \mu \mathrm{g} \cdot \mathrm{mL}^{-1}$.

A study conducted on five onion cultivars, with two whites (the landrace openpollinated Branca da Povoa and the hybrid SK409) and three reds (Vermelha da Povoa, Red Creole, and a line of Vermelha da Povoa), suggested that small onions appear to have higher levels of anthocyanin and flavonoid content than larger onions (PérezGregorio et al., 2010). However, our results did not agree because 'Lambada' displayed the lowest levels of anthocyanin in late plantings when bulb sizes were smaller. Our results also showed that anthocyanin is mostly attributed to cultivar rather than skin color.

The total antioxidant capacity (AOA) measured by the DPPH assay was significantly different from onion cultivar and planting date. 'Lambada' consistently displayed the highest levels, $33 \mathrm{GAE} \mu \mathrm{g} \cdot \mathrm{mL}^{-1}$, followed by 'Don Victor' with medium levels, 18.6 GAE $\mu \mathrm{g} \cdot \mathrm{mL}^{-1}$; and 'Caramelo' which showed the lowest in AOA levels, 16.1 GAE $\mu \mathrm{g} \cdot \mathrm{mL}^{-1}$. Yoo et al. (2011) evaluated AOA in white, yellow, and red cultivars, and observed the same tendency with red onions displaying the highest AOA values (1.64 GAE $\left.\mu \mathrm{g} \cdot \mathrm{g}^{-1} \mathrm{FW}\right)$. In general, the highest levels of AOA were obtained from onions transplanted in December (average of 26 GAE $\mu \mathrm{g} \cdot \mathrm{mL}^{-1}$ ) and November (22.6 GAE $\mu \mathrm{g} \cdot \mathrm{mL}^{-1}$ ), with low levels during January (19.3 GAE $\left.\mu \mathrm{g} \cdot \mathrm{mL}^{-1}\right)$.

This study investigated growth, yield, and quality of three onion cultivars (Caramelo, Don Victor, and Lambada) in response to planting dates (early, mid, and late), seedling densities (T1 and T3), and transplant growing location (Alamo, TX, and Ruskin, FL). Early season (November) extended the number of days to reach maturity. Conversely, mid (December) and late (January) transplanted onions reduced the number of days required to reach maturity because of temperature and daylength increases. Time of planting is a critical strategy to regulate bulb category distribution, with early planting increasing the number of bulbs in the category of jumbo and colossal categories (most valuable), whereas mid to late plantings increase the number of bulbs in the medium size. Furthermore, determining the best transplanting date for short-day onions is important to minimize overwinter losses and bolting susceptibility, while maximizing yield and quality.

Compared with direct seeding, transplants can reduce the field growing period, reducing the time of exposure to environmental and biological stresses (Leskovar et al., 2004a). Transplanting gives growers early harvests and is more efficient when considered the high cost of hybrid seeds. Containerized transplants grown from three plants per cavity transplanted in early November can be an alternative and cost-effective system that could increase yield over direct seeding system.

In terms of quality, the overall AOA levels and anthocyanin levels were mostly affected by cultivar (Lambada $>$ Don Victor $=$ Caramelo) and not by planting date and seedling density.

In conclusion, delaying the transplanting date can significantly decrease the onion growing period in the field, thus reducing potential biotic and abiotic stresses affecting growth, development, and yield. In addition, the technique of establishing onions from multiseeded transplants (T3) provides a practical and economical alternative to produce earlier crops, with competitive yields. Nonetheless, growers need to consider that interplant competition during early development in the flat trays during the nursery period could reduce transplant size and influence posttransplant development, especially under extreme cold or freezing temperatures.

\section{Literature Cited}

Arce, J.P. 1995. Effect of planting date, nitrogen rate, and in-row plant spacing on the maturity, diasease infection severity, pungency, bolting and doubling incidence, and yield of selected short-day onions. Texas A\&M Univ., College Station, TX, PhD Thesis.

Boyhan, G.E., R.L. Torrance, J. Cook, C. Riner, and C.R. Hill. 2009. Sowing date, transplanting date, and variety effect on transplanted short-day onion production. HortTechnology 19:66-71.

Brewster, J. 1994. Onion and other vegetable Allium. International Cambridge, Wellington, UK.

Brewster, J. 1997. Environmental physiology of the onion: Towards quantitative models for the effects of photoperiod, temperature and irradiance on bulbing, flowering and growth. Acta Hort. 433:347-374.

Brewster, J., W. Lawes, and A. Whitlock. 1987. The phenology of onion bulb development at different sites and its relevance to incomplete bulbing ('thick-necking'). J. Hort. Sci. 62:371378 .

Brewster, J.L. 1990a. Onion and allied crops: Botany, physiology and genetics. CRC Press, Boca Raton, FL.

Brewster, J.L. 1990b. Onions and allied crops: Agronomy, biotic interactions, pathology and crop Protection. In: D. Rabinowitch and J.L. Brewster (eds.). Cultural system and agronomic practices in temperate climates. CRC Press, Boca Raton, FL.

Caruso, G., S. Conti, G. Villari, C. Borrelli, G. Melchionna, M. Minutolo, G. Russo, and C. Amalfitano. 2014. Effects of transplanting time and plant density on yield, quality and antioxidant content of onion (Allium cepa L.) in southern Italy. Scientia Hort. 166:111-120.

Coolong, T.W. and W.M. Randle. 2003. Temperature influences flavor intensity and quality in granex 33 onion. J. Amer. Soc. Hort. Sci. 128:176-181.

Corgan, J.N. and N. Kedar. 1990. Onion cultivation in subtropical climates, p. 31-47. In: H.D. Rabinowitch and J.L. Brewster (eds.). Onions and allied crops. CRC Press, Boca Raton, FL. 
Currah, L. and F.J. Proctor. 1990. Onions in tropical regions. Natural Resources Institute, Overseas Development Administration, Kent, UK.

De Ruiter, J. 1986. The effect of temperature and photoperiod on onion bulb growth and development. Agron. Soc. N.Z. 16:93-100.

El-Rehim, G., F. Ahmed, G. Shalaby, and A. Waly. 1997. Effect of transplanting date and planting density on bulb yield and quality of Giza 20 onion in upper Egypt. Egyptian. J. Agr. Res. 75:681-695

Finch-Savage, W. and K. Phelps. 1993. Onion (Allium cepa L.) seedling emergence patterns can be explained by the influence of soil temperature and water potential on seed germination. J. Expt. Bot. 44:407-414.

Gaskell, M. 1998. Effect of transplant date and transplant size on production, quality and pungency of sweet onions. Newsletter Articles, Small Farms and Specialty Crops.

Griffiths, G, L. Trueman, T. Crowther, B. Thomas, and B. Smith. 2002. Onion-A global benefit to health. Phytother. Res. 16:603-615.

Hamilton, B.K., K.S. Yoo, and L.M. Pike. 1998. Changes in pungency of onions by soil type, sulphur nutrition and bulb maturity. Scientia Hort. 74:249-256.

Hatridge-Esh, K. and J. Bennett. 1980. Effects of seed weight, plant density and spacing on yield responses of onion. J. Hort. Sci. 55: 247-252.

Jackson, K., A.A. Duff, and W.E. O’Donnell. 1997. Development of a suite of onion varieties for the subtropical region of the Lockyer Valley in SE Queensland, Australia. Acta Hort. 555:239_ 242.

Kandil, A.A., A.E. Sharief, and F.H. Fathalla. 2013. Effect of transplanting dates of some onion cultivars on vegetative growth, bulb yield and its quality. Crop Production 2:72-82.

Khokhar, K., N. Kaska, S. Hussain, K. Qureshi, and T. Mahmood. 1990. Effect of different sowing dates, direct seeding and transplanting of seedling on maturation, bulb weight and yield in onion (Allium cepa) cultivars. Indian J. Agr. Sci. 60:668-671.

Lancaster, J.E. and M.J. Boland. 1990. Flavor Biochemistry, p. 33-72. In: J.L. Brewster and H.D. Rabinowitch (eds.). Onion and allied crop. CRC Press, Boca Raton, FL.

Lee, E.J., K.S. Yoo, J. Jifon, and B.S. Patil. 2009. Characterization of shortday onion cultivars of 3 pungency levels with flavor precursor, free amino acid, sulfur and sugar contents. J. Food Sci. 74:475-480.

Lee, J.E., B.S. Patil, and K.S. Yoo. 2015. Antioxidant of 15 onions white, yellow, red colors and their relationship with pungency and quercetin. Food Sci. Technol. 63:108-114.

Leskovar, D., M. Cantamutto, P. Marinangelli, and E. Gaido. 2004a. Comparison of direct-seeded, bareroot, and various tray seedling densities on growth dynamics and yield of long-day onion. Agronomie 24:35-40.

Leskovar, D.I., K. Kolenda, K.S. Yoo, and L.M. Pike. 2004b. Containerized transplants and subsurface drip improved yield and quality of short-day onions. Acta Hort. 631:155-160.

Leskovar, D.I., S. Agehara, K. Yoo, and N. Pascual-Seva. 2012. Crop coefficient-based deficit irrigation and planting density for onion: Growth, yield, and bulb quality. HortScience 47:31-37.

Leskovar, D.I. and S.C. Vavrina. 1999. Onion growth and yield are influenced by transplant tray cell size and age. Scientia Hort. 80:133143.

Mettananda, S.A. and Sr. Fordham. 1999. The effects of plant size and leaf number on the bulbing of tropical short-day onion cultivars (Allium cepa L.) under controlled environments in the United Kingdom and tropical field conditions in Sri Lanka. J. Hort. Sci. Biotechnol. 74:622-631.
Middleton, E., C. Kandaswami, and T.C. Theoharides. 2000. The effects of plant flavonoids on mammalian cells: Implications for inflammation, heart disease, and cancer. Pharmacol. Rev. 52:673-751.

Patil, D., A. Dhake, P. Sane, and V. Subramaniam. 2012. Studies on different genotypes and transplanting dates on bulb yield of high solid white onion (Allium cepa L.) under short-day conditions. Acta Hort. 969:143-148.

Peffley, E.B., M. Ortiz, and J.N. Corgan. 1981. A technique for onion cold hardiness evaluation: Effects of plant age and size on hardiness. HortScience 16:773.

Pérez-Gregorio, R.M., M.S. García-Falcón, J. Simal-Gándara, A.S. Rodrigues, and D.P.F. Almeida. 2010. Identification and quantification of flavonoids in traditional cultivars of red and white onions at harvest. J. Food Compos. Anal. 23:592-598.

Platenius, H. and J. Knott. 1941. Factors affecting onion pungency. J. Agr. Res. 35:681-684.

Richwine, P. 1990. Effect of fall planting date on bulb yield of sweet winter onion in the rolling plains of Texas. HortScience 25:981.

Rubatzky, V.E. and M. Yamaguchi. 1997. Vegetables consisting of succulent roots, bulbs, leaves and fruits, p. 279-304. In: Science (ed.). World vegetables: Principles, production and nutrient values. AVI, Wesport, CT.

Tesfay, S.Z., I. Bertling, A.O. Odindo, P.L. Greenfield, and T.S. Workneh. 2011. Growth responses of tropical onion cultivars to photoperiod and temperature based on growing degree days. Afr. J. Biotechnol. 10:15875-15882.

USDA. 2016. Vegetables and pulses production yearbook data (online). In: Service., U.N.A.S. (ed.).

Yoo, K.S., E.J. Lee, and B.S. Patil. 2011. Underestimation of pyruvic acid concentrations by fructose and cysteine in 2,4-dinitrophenylhydrazine-mediated onion pungency test. J. Food Sci. 76:11361142 